Anne Beatly is an assistant professon of accounting at the Wharton School of the University of Pennsylvanin and was a visiting scholar at the Federal Reserve Bank of St. Louis. Thomas A. Pollfnann and Neno Wooldridge provided research assistance. The Wharton Financial Institution Center and the SEC Financial Reporting Instifute provided financial assistance.

\section{The Effects of Fair Value Accounting on Investment Portfolio Management: How Fair Is It?}

\section{Anne Beathy}

uring the late 1980s, the Securities and Exchange Commission (SEC) challenged the use of historical cost accounting for financial instruments because this method values these assets using the interest rate in effect at the purchase date. Thus, it does not reflect changes in values that arise from changes in market interest rates. In a 1992 address to the American Accounting Association, Walter Schuetze, the chief accountant of the SEC, claimed the magnitude of losses in the thrift industry were increased by a lack of regulatory discipline made possible by the use of historical cost accounting.' He argued that regulators were able to avoid making decisions about capital adequacy in the thrift industry when estimates of the deficit in net worth of the industry on a market value basis were as high as $\$ 118$ billion, because the net worth of the industry on a historical cost basis was positive. The experience in the thrift industry, combined with the large number of bank failures in the 1980s, caused former SEC Chaiman Richard Breeden to express concerns that historical cost accounting might contribute to even larger losses in the banking industry."

In a 1990 letter, the SEC lobbied accounting rulemakers to require financial institutions to use market values when accounting for securities investments.
The letter argued that historical cost accounting produces information that is irrelevant to valuing investment portfolios and provides an opportunity for managers to manipulate the numbers reported in financial statements. ${ }^{3}$ The Financial Accounting Standards Board (FASB) responded by adopting Statement of Financial Accounting Standards Number 115 (SFAS 115) in May of 1993. This statement requires that investment securities be valued using market interest rates, and requires that equity accounts be adjusted to reflect changes in these fair, or market, values. ${ }^{4}$

The adoption of this standard has been controversial. Opponents of fair value accounting have objected to the new standard because it focuses on a single type of asset. Bankers and regulators have claimed that the mismatching caused by ignoring concurrent changes in the values of other assets and liabilities such as loans and deposits will induce unrealistic volatility in bank equity. Bankers claim that efforts to mitigate this increase in volatility will result in reductions in the proportion of assets held in investment securities, the maturity of investments held, and in the flexibility of investment portfolio management.

These arguments were important in the recent decision by regulators to exclude the effects of SFAS 115 from the definition of regulatory capital ratios. In addition, bankers argue that the new standard will not eliminate the opportunity to manipulate the financial statements.

The arguments by both sides rely on the assumption that actions by regulators, investors, or depositors and creditors are based strictly on the numbers reported in the financial statements. This assumption is important in the debate over the effects of this accounting change because financial statement disclosures contain the information necessary to restate the investment account from a cost- to a fair-value basis.

This article examines the adoption of SFAS 115 by bank holding companies to determine if a desire to influence the

\footnotetext{
Hits speed, which was entittao o "Relevonce ond Gerdibility in Firenciol Accountiting and Reporting," was given on Atugust 12, 1992, of the tintud neeting of the Ametican Accounting Assogidition.

${ }^{2}$ See the Wall Street Jound (Sepiember 27, 1990).

${ }^{3}$ See the Woll Street Journol (Septefilger 14, 1990).

"The FASB uses the term foil value to include the maket value of itenss an traded on active secontany nakets. See SFAS 175 , parograph 109.
} 
numbers in the financial statements, including reported equity volatility, affects investment portfolio management. The focus of this article is on whether investment portfolio management was changed by the adoption of SFAS 1.15. I did not attempt to verify the claims of bankers and regulators that these changes will reduce income earned from investment securities or increase exposure of the market value of banks to interest rate changes. Evidence in this article suggests that SFAS 115 did affect investment portfolio management, and it suggests the need for further research.

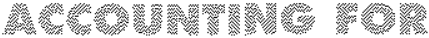

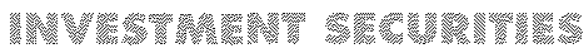

In May of 1993, the FASB issued SFAS 115, which must be followed in fiscal years beginning after December 15, 1993. The standard could have been adopted at the end of an earlier fiscal year if the annual financial statements for that year were issued after May of 1993. For bank holding companies whose fiscal year ends in December, SFAS 115 could be adopted as of December 31, 1993, or for the year beginning January $1,1994$.

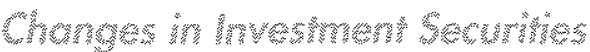

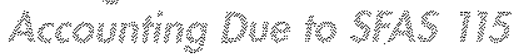

Prior to implementation of SFAS 115, debt securities that banks intended and were able to hold on a long-term basis were carried at amortized cost with no adjustment for changes in value resulting from changes in interest rates. Equity securities and debt securities that might be disposed of in the foreseeable future, in contrast, were accounted for at the lower of cost or market. This method requires that declines in the value of securities be recorded as an adjustment to equity, but does not allow increases in the value of these securities above cost to be recorded. Sales of securities, whether accounted for at amortized cost or the lower of cost or market, resulted in a gain or loss from the sale equal to the difference between their sales price and their amortized cost. This gain or loss was recorded in both income and equity. Finally, debt securities held for trading were recorded at their market values.
Although most securities were recorded in the financial statements at amortized cost prior to adoption of SFAS 115, information about the market value of these securities was disclosed in the foomotes to the annual reports. Typically, this footnote information was also provided on the face of the balance sheet. The availability of information about both the amortized cost and the market value of investment securities at both the beginning and ending financial statement dates made it possible for users of the financial reports to restate the financial statements to the values that would have been recorded if investment securities were accounted for at market values.

SFAS 115 requires that each security be placed into one of three portfolios depending on the reason for acquiring the security and on whether the security will be held to maturity, resold in the near term, or avalable for sale in some intermediate period. Accounting for the income generated from these securities and for the acquisition and sale of the securities was not changed by SFAS 115 and is the same regardless of the classification of the security. The accounting treatment of unrealized holding gains and unrealized holding losses differs for the securities in each of these three categories.

Securities held to maturity are debt securities that management intends to hold until maturity. Securities in the held-to-maturity portfolio are recorded at amortized cost. No unrealized gains are recognized. Unrealized losses are recognized only if there is a large and permanent decline in the fair value of the security.

Held-to-maturify securities are allowed to be sold or transferred to one of the other two portfolios for the following reasons: deterioration in issuer's creditworthiness; change in the tax law affecting the tax-exempt status of interest on debt security; a major business combination or disposition by the reporting entity; change in regulation modifying permissible level of an investment; or significant change in risk weights used in computing risk-based capital. The following are not acceptable reasons for selling or transferring securities from the held-to-maturity portfolio: change in market interest rates; need for liq. uidity; change in yield on other investments: 
change in funding sources and terms; or a change in foreign currency risk. In addition, sales of debt securities are allowed if they occur near enough to the maturity date so that interest tate risk is substantially eliminated as a pricing factor (for example, within three months), or if they occur after at least 85 percent of the principle outstanding at acquisition has been collected. ${ }^{5}$

The FASB has not established a penalty for unauthorized sales or transfers of heldto-maturity securities. Banks that make unauthorized dispositions from this portfolio will most likely find it difficult to convince auditors and regulators that they intend to hold other securities to maturity. As a result, these banks may be required to re-classify all securities in the held-to-maturity portolio to one of the other two portfolios.

Trading securities are debt or equity securities bought and held principally for the purpose of selling them in the near term. Trading securities are recorded at market value with unrealized gains and unrealized losses recognized in income. Thus, the accounting treatment for trading securities was not affected by SFAS 115.

Securities avalable for sale are debt or equity securities not classified as trading securities or as held-to-maturity. Securities in the available-for-sale portfolio category are recorded at market value with unrealized gains and losses (net of tax) recorded as a separate component of shareholder's equity. Changes in the market value of these securities are not recorded in income.

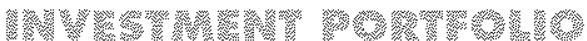

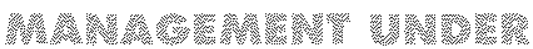

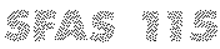

Bank managers can use the investment securities portfolio to achieve several objectives. The investment portfolio provides a source of interest income, collateral to secure deposits and other liabilities, liquidity to meet needs that arise from fluctuations in deposit and loan balances, and cash flows from assets that can be matched with those from liabilities to reduce interest rate risk. In addition, to the extent there are gains or losses on investment securities not yet recognized in either equity or earnings, sales of investment securities can provide management with an opportunity to influence reported equity or earnings.

Prior to SFAS 115, there were few restrictions on the use of investment securities to achieve these objectives. Under SFAS 115 , use of securities classified as available-for-sale is still unrestricted, but the virtual prohibition of the sale of securities classified as held-tomaturity dramatically reduces the usefulness of these securities in investment portfolio management. Held-to-maturity securities will still provide the bank with interest income, but these securities will not be available to manage liquidity or interest rate risk, or to influence reported equity or earnings because they can be sold only under very restrictive conditions or with the penalty of re-classifying this portfolio as available-for-sale. Without some offsetting benefit, these severe resirictions on the use of held-to-maturity securities suggest that bank managers would not choose to classify any of their securities in this portfolio. The only advantage of classifying securities as held-to-maturity rather than available-for-sale is that unrealized gains and losses will not be recorded in equity. The relative costs and benefits of classifying securities as heldto-maturity will depend on how actively the investment portfolio is managed, and how costly it is to include unrealized gains and losses on investment securities in reported equity.

\section{The lwerrotonce of wAS 115 in Brmen hegulotion}

In December of 1993, the Board of Governors of the Federal Reserve System proposed that capital requirements be amended to include unrealized holding gains and losses on securities available for sale in Tier 1 capital, despite arguments made by Federal Reserve Chairman Alan Greenspan that SFAS 115 would result in a distortion of bank financial statements and would erect barriers to effective interest. rate risk management.' The proposal stated that the amendment was consistent with the intent of the requirement in the Federal Deposit Insurance Corporation Improvement Act of 1991 (FDICIA) that regulatory

\footnotetext{
5 See SFAS 115 , paraggapis \& 811.

${ }^{5}$ Tier 1 Capittel is defined in the Boont af Governors of the Federtit Resenve System Copital Adeguacy Guidelines as: Commen equity, quallying nencumulative perpetud prefersed stock, and minority interests less goodwill and oither intergible assets requentert to be deducted from capital.

'See The Wall Street Jownd (thovembes 8, 1990; and Januar 18, 1993).
} 
accounting standards be no less stringent than Generally Accepted Accounting Principles (GAAP), and noted that including the unrealized gains and losses in Tier 1 capital would affect prompt corrective action regulations, brokered deposit restrictions, and the risk-related insurance premium system.

Given the language used in the proposed amendment to the capital requirements, it seems reasonable that at the time bank managers implemented SFAS 115, they would have assumed that the resulting unrealized holding gains or losses would be included in Tier 1 capital. In November of 1994, however, the Board of Govemors decided not to include the effects of SFAS 115 in Tier 1 capital. This decision, which occurred after SFAS $115 \mathrm{had}$ been required for financial reporting purposes for three quarters, may cause banks to adjust their investment portfolio holdings.

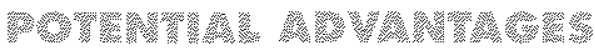

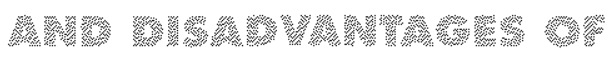

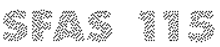

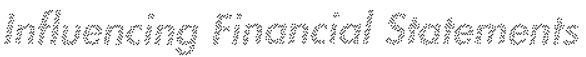

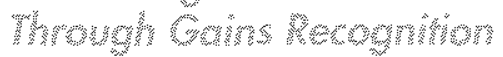

Fair value proponents have criticized historical cost accounting because it provides the potential for manipulation of the numbers reported in the financial statements through the sales of investment securities. This criticism also applies to the fair value accounting required by SFAS 115. The new standard actually increases the potential for certain types of manipulation.

SFAS 115 does not eliminate opportunities to influence the numbers that are reported in the financial statements. When this standard was implemented, there was an adjustment to equity equal to the after-tax net unrealized gain or loss on the securities classified as available-for-sale. This change provided managers with a transitory ability to affect reported equity. First, managers could affect the timing of this adjustment through the choice of when to adopt the standard. Second, managers can affect the amount

${ }^{8}$ Banks javest pirmatily in U.S. Trensury and US. agency secusitites,

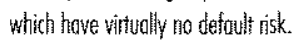

of the adjustment through the selection of securities for classification as available-for-sale. In addition, after SFAS 115 is in place, managers will still be able to influence reported earnings through the recognition of gains or losses on securities sales. SFAS 115 reduces the restrictions on sales of securities classified as available-for-sale.

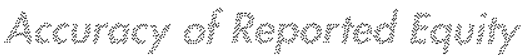

Fair value proponents also argue that improving the measurement of the investment securities account by using fair value rather than historical cost accounting will improve the measurement of equity. Although this would certainly be true if the values of assets and liabilities were uncorrelated, it need not be the case when they are related. Changes in interest rates primarily cause changes in the market values of the investment securities held by banks. ${ }^{.}$Changes in interest tates also cause changes in the values of other bank assets, such as loans, and changes in the values of bank liabilities, such as deposits and long-term debt. The values of these assets and liabilities are therefore likely to move together. This is especially true when the investment portfolio is used to hedge the effects of interest rate changes on equity. For this reason, the volatility in reported capital that will occur as a result of stating only the investment portfolio at market value may not be indicative of the true risk of the bank. Fair value accounting will provide managers with an incentive to reduce the volatility in reported equity, assuming that those who use financial statements do not adjust for the effects of unrealized securities gains and losses.

A number of theoretical and empirical studies have evaluated market value accounting systems in which all assets and liabilities are marked to market. For example, see: Berger, King and O'Brien (1991); Shaffer (1992); and Mengle and Walter (1991). Partial market value accounting, with only one category of assets recorded at market value, has received relatively less attention.

Two studies examining past changes in the market value of banks' investment portfolios have concluded that the effects of implementing SFAS 115 are likely to be small. Barth, Landsman and Wahlen (1995) document an increase in volatility of reported equity during 1970-90, when changes in 
investment securities values are included in equity. They argue, however, that this increase in volatility is not important to investors or regulators. In a study of the effects of market value accounting for investment securities on regulatory discipline, Carey (1995) reaches no conclusion about whether regulatory discipline will be improved or worsened, but does conchude that the effects are likely to be small. Both papers acknowledge that there are limitations on the inferences that can be drawn from past data, since bank behavior will likely be different once SFAS 115 is in effect.

In contrast, Ernst and Young (1993) report that more than half of respondents to their survey anticipated altering their investment behavior if SFAS 115 were adopted. Ernst and Young (1994), however, report that 60 percent of the respondents to a follow-up survey claimed to have actually changed their investment strategies as a result of adopting SFAS 115. More than 95 percent of respondents in the original survey claimed they would shorten the maturity of debt securities held, and roughly 40 percent said they would increase their hedging activity. In addition, respondents said they might reduce the proportion of assets held in investment securities. In the follow-up survey, the respondents said they had shortened the maturity and duration of their portfolio and had reduced their holdings of mortgagebacked securities and mortgage derivatives. The fraction claiming they would increase their hedging activity was reduced to roughly 10 percent.

Under SFAS 115, any change in the after-tax net unrealized gain or loss on the securities in the available-for-sale account will result in an adjustment to equity, resulting in an increase in the volatility of the reported equity balance. This volatility in reported equity will be higher as more securities are included in the available-for-sale account and the more sensitive these securities are to changes in interest rates.

Bank managers who want to minimize the increase in volatility of reported equity that will result from adopting SFAS 115 can either classify securities as held-to-maturity or change their investment security holdings to minimize the effect on reported equity. The second option can be achieved either by reducing the proportion of total assets held in the investment portfolio or reducing the sensitivity of the value of investments held to changes in interest rates. Since the sensitivity of securities' values to changes in interest rates increases with their maturity, reducing the maturity of the investment portfolio will decrease the volatility in reported equity caused by changes in the values of available-for-sale securities.

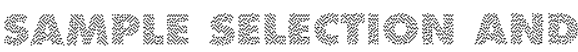

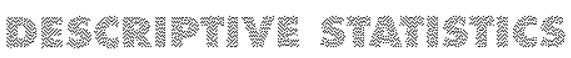

Bank holding company data during the implementation period of SFAS 115 are used to examine wo aspects of investment portfolio management. First, I ask whether the decision about when to adopt this accounting standard was affected by the transitory ability to influence reported equity. Second I explore whether bank managers' desire to reduce volatility in reported equity affects the proportion of assets held in investment securities, the maturity of the investment securities held, and the proportion of securities held in the available-for-sale portfolio. A sample of bank holding companies was identified from the consolidated fnancial statement for the bank bolding companies report (FR Y-9C) filed with the Federal Reserve System during the second quarter of 1993 through the first quarter of 1994 . In addition to the data available from this file, information from the annual report footnote disclosures was required to determine when SFAS 115 was adopted and to obtain data on the proceeds of sales from the investment portiolios.

$P$ ublicly traded companies are required to file annual reports with the SEC. Therefore, to be retained in the sample, the holding company also had to be listed on the New York Stock Exchange, American Stock Exchange, National Association of Stock Deals Automated Quotation System, or over-the-counter. This matching resulted in a sample of 369 bank holding companies as of December 31, 1993. Bank holding companies were eliminated from the sample if their annual reports could not be obtained directly from the company 
or from the National Automated Accounting Retrieval Services database. This requirement resulted in the exclusion of 78 bank holding companies. Bank holding companies were also eliminated if they did not report the proceeds from sales of investment securities, and 40 bank holding companies failed to report proceeds data.

Table 1 provides definitions of characteristics used to analyze the effects of implementing SFAS 115 by bank holding companies. Table 2 profiles bank holding companies included in the sample by peer group. As of September 30,1993 , the sample bank holding companies had assets ranging from $\$ 157$ million to $\$ 221$ billion, and are fairly evenly distributed within the six peer groups represented. Due to the exclusion of bank holding companies with missing data, the average size of the sample bank holding companies of $\$ 10.921$ billion is slightly larger than the average of $\$ 7.796$ billion for all publicly traded bank holding companies.

Many characteristics of bank holding companies differ across peer groups. The average leverage ratio decreases with average bank holding company size, while the average return on equity increases. SFAS 115 affects reported equity and therefore will affect the numerator of the leverage ratio and the denominator of the return on equity. Both the existence of interest rate contracts and the average portfolio turnover are increasing with bank holding company size. These variables suggest that larger bank holding companies are more active in liquidity and interest rate risk management and therefore may be affected more by SFAS 115 . Slightly more than 44 percent of sample bank holding companies adopted SFAS 115 during the fourth quarter of 1993. This fraction, although different across peer groups, does not increase uniformly with bank holding company size.

Table 3 compares the characteristics of early and late adopters of SFAS 115 . On average, early adopters of SFAS 115 have lower leverage ratios, higher past excess gains, and investment securities with longer maturities. Although early adopters decreased the fraction of their assets held in the investment portfolio and decreased the maturity of the securities held in their investment portolios more in the fourth quarter of 1993 and less in the first quarter of 1994 than did late adopters, these mean differences are not statistically significant.

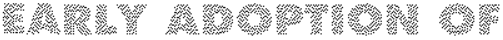

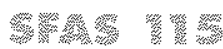

As of the end of 1993, 93 percent of all publicly traded bank holding companies had net unrealized gains in their investment portfolios. By adopting SFAS 115 early, this unrealized gain could be used to increase reported equity. A probit model of the decision to adopt SFAS 115 in 1993 rather than waiting until 1994 is estimated to determine if the ability to increase reported equity influences the decision about when to adopt this standard.

The probit model includes three variables used to test whether the increase in reported equity resulting from the adoption of SFAS 115 was important in the decision to adopt early. Bank holding companies with lower leverage ratios are predicted to be more concerned with increasing reported equity and, therefore, more likely to be early adopters. Similarly, bank holding companies with higher returns on equity are predicted to be more willing to report an increase in equity, thereby reducing this measure of performance commonly used by regulators and investors. Finally, bank holding companies that have managed their securities portfollos in the past to increase reported equity are predicted to be more likely to adopt SFAS 115 early.

Carey (1994) points out that a bank can increase captal by selecting securities for sale with an average unrealized gain larger than the average for all securities in the investment portfolio. Past excess securities gains are used to measure differences across bank holding companies in their desire to boost reported capital.

These variables are likely to be related to other bank holding company characteristics such as size and structure of the investment portfolio. The probit model also includes several control variables to capture other factors that may be iroportant in the decision about when to adopt SFAS 115.

Implementation of SFAS 115 is likely to require a change in investment management, which may require a great deal of planning. 


\section{Identifieation of Characteristics}

\begin{tabular}{|c|}
\hline torly udoption \\
\hline Leverage ratio \\
\hline leveroge rotio, \\
\hline Leveroger rotio ${ }_{3}$ ingte \\
\hline Leveroge rotio ${ }_{35}$ : \\
\hline Averoge lavernge roilo \\
\hline Roiver on equily \\
\hline Avergge sefun on equity \\
\hline Gest portolos lundever \\
\hline Past excessgons \\
\hline Iostgoins \\
\hline Uneculized holding goins \\
\hline Interestrole conreds \\
\hline Investnents: \\
\hline livestnentstraencess? \\
\hline Invesinents, \\
\hline Inestnent, \\
\hline Investuent \\
\hline$\triangle$ lnvesinent: \\
\hline Alnusinent \\
\hline$\triangle$ lnvesiment, \\
\hline Avallable lor sole \\
\hline Peen \\
\hline
\end{tabular}

1 I SEAS 115 was odopted os of December 3 , 1993 , 0 otherwise the ratio of tier 1 capifal to to tal assets os of September 30,1993

1 if the leveroge totio is above the 75 th percentile of sample bank holding companies as of September 30, 1993 , o ohewise

1 if the leveruge rotio is between the 50 h and 75 th percentile of sample bonk holding companies as of September 30 , 1993 , 0 otherwise

I if the leveroge rotio is befueen the 25 th and 50 h percentile of somple bank holding conpanies os of Septemier 3019930 othervise

the avercge leverage rotio for the fourth quarfer of 1990 lhough fle fourth quarter of 1992 net incene for he first thee quarters of 1993 divded by equity as of September 30 \% 1993 the average Refurn on Equity for the third quarter of 1990 through the fouth quarter of 1992 the aniud proced from sales of securifies divided by the natike value of the securities averoged for 19901992

he average of securities gains realized less the product of the aet unrealized gains and the portfolo turnover divided by ossets for 19901992

securifes gains redized divided by ossets avenged for the foutll guarter of 1990 through the fourtinguoter of 1992

the moket velue less the book value of investnent seanties divided thy fotal ossets os of Septenber 30,1993

1 if en titerest rote tontrat wos held os of September $30,1993,0$ otherwise the took value of investment securities netering within 1 year duddad by todol ossets as of sune 30 , 1993 the bool value of investment securites naturing in noore thon I and less then 5 years divided by total ossets os of June 30,1993

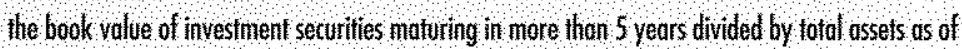
Jute 30,1993

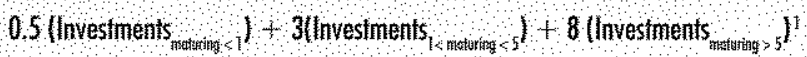
he book value of investinenl securtites divided by tofal assets he dionge n lavestnentWA the dhange in lwwestment $\Delta$ lavestment $-\Delta$ Investmen (Investment, the book value of securities clossified os ovaloble for sale divided by the book value of totol investnent sectrities as of Mardi 31,1994

1 tor bonk holding componies in Peer Group o o oherwise

"Assumes that the maturity of securities in these categoties equals the overoge of the mininum and moximum moturity for the category is consistent with the assumption made in the proposal to revise risk-based copitcl standards to arcount for interest rate risk.

Some bank holding companies may be able to respond to this new reporting requirement more quickly than others. Indicator variables for the bank holding companies' peer group are included to control for these factors, and to control for other differences among bank holding companies that depend on size such as differences in average capital ratios and differences in average return on equity.

An indicator variable for whether the bank holds interest rate contracts such as swaps, forwards and purchased options is included to capture differences in how bank holding companies manage their interest rate risk. Bank holding companies that use interest rate contracts to manage interest rate risk are expected to be more likely to alter their investment strategies as a result of SFAS 115. This may be important in the decision about when to adopt this accounting standard. Similarly, variables measuring the maturity of the investment portfolio are included since these 
Shes

\section{Mean Value of Characteristics by Peer Group}

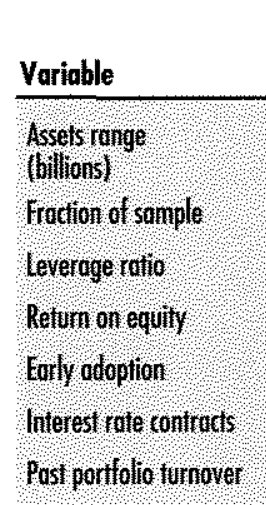

\begin{tabular}{ccccc}
\multicolumn{5}{c}{ Peer Group } \\
1 & 2 & 3 & 4 & 5
\end{tabular}

\section{ath}

Mean Value of Characferistics
of Early and Late Adopters of
SFAS 115

Varioble

\begin{tabular}{|c|c|c|}
\hline Leveroge rolio & 0075 & 0083 \\
\hline Average leverge roilo & $0: 069$ & 0.077 \\
\hline Reum on equily & 0102 & 0080 \\
\hline Arerage returtic on equity & 0.020 & 0.026 \\
\hline Post portolo unnover & 0.174 & 0.153 \\
\hline Unredized lobling goiss & 0.007 & 0.008 \\
\hline Bast excess gans $10 /$ & -0.028 & $-0.050^{*}$ \\
\hline Interest rote controts & 0.523 & $0.336^{* *}$ \\
\hline nestinents, & 0,055 & 0061 \\
\hline 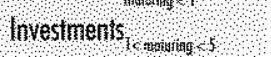 & 009 & $0121^{* * *}$ \\
\hline levesiments, & 0.127 & $002^{* * *}$ \\
\hline nussment & 3.316 & $1.127^{* *}$ \\
\hline$\triangle$ nvestment & & \\
\hline tourlt quarler 1993 & -0.009. & 0.009 \\
\hline Iirst quoter 1994 & 0.070 & 0.041 \\
\hline Anussment & & \\
\hline lourth quorter 799 & 0001 & 0.007 \\
\hline firs cutreer 1994 & 0.004 & 0.001 \\
\hline$\Delta$ nestment, & & \\
\hline foutll quatter 1993 & -0.005 & 0.005 \\
\hline first quester 1994 & 0.060 & $0.03 \%$ \\
\hline
\end{tabular}

Hote: ****** and * inticate that the difference in the means for ently ond late adopters is stctistically different from zaro at the $0.01,0.05$ and 0.10 leves. variables may be important in explaining the reaction to this accounting standard and, thus, the decision about when to adopt SFAS 115.

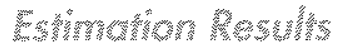

Table 4 shows the results of the probit estimation of the decision to adopt SFAS 115 in 1993 versus 1994, including alternative combinations of the explanatory variables. Evidence consistent with SFAS 115 being adopted early to increase reported capital is provided by coefficients on the leverage ratio, return on equity, and the past excess gains recognized.

The significantly negative coefficient on the leverage ratio indicates that companies with lower capital are more likely to increase their reported equity by adopting SFAS 115 early. Similar evidence is provided by the coefficients on the indicator variables that measure the percentile of the leverage ratio. Companies whose leverage ratio falls in the top $75 \mathrm{th}$ percentile were significantly less likely than those whose leverage ratio falls in the bottom 25 th percentile to adopt SFAS 115 early. The same is true for those who fall between the 50 th and 75 th percentile, although the reduction in probability is lower for this gromp. Those that fall between the 25 th and 50 th percentile are not found to be significantly less likely than those in the bottom 25 th percentile to adopt SFAS 115 early. The coefficient estimates on these three indicator variables suggest the decline in probability of early adoption is lnearly related to the increase in the leverage ratio.

The significantly positive coefficient on retum on equity provides further evidence that the effect on reported equity of SFAS 115 is importan in the decision to adopt early. This suggests that companies performing well in 1993 were nore willing to have this measure of performance reduced by the increase in equity that occurred as a result of adoping SFAS 115 early

Finally, the positive coefficient on the excess gains variable, which is significant when the investmet control variables are included, suggests that companies that have boosted reported equity in the past through the disproportionate recognition of securities gains 
are more likely to adopi SFAS 115 early to increase their reported equity during 1993.

The coefficients reported in Table 4 provide estimates of the changes in probability of early adoption of SFAS 115, given changes in the corresponding variable. Therefore, a coefficient of -2.766 on the leverage ratio indicates that increasing the leverage ratio from the Peer 1 group average of 0.070 to the Peer 6 group average of 0.084 would result in roughly a 3.9 percent decline in the probability of adopting SFAS 115 early. Similarly, a coefficient of 0.438 on return on equity indicates that decreasing the return on equity from the Peer 1 group average of 0.127 to the Peer 6 group average of 0.050 would result in roughly a 3.4 percent decline in the probability of adopting SFAS 115 early.

Once other characteristics have been controlled for, the size of the bank holding company generally does not appear to be important in the decision to adopt SFAS 115 early, although bank holding companies in Peer group 3 are more likely than those in Peer group 1 to adopt early. The only other variables that are significant in explaining the early adoption decision are the amount of securities maturing in more than one year and less than five years, and the existence of interest rate contracts. Inclusion of these. variables does not alter the conclusions drawn from the coefficients on the other variables included in the estimation.

The mean predicted probability of adopting SFAS 115 early is significantly higher for early adopters than for late adopters for all three probit models estimated. In addition, the fraction of bank holding companies correctly classified as early versus late adopters for all three probit models is significantly better than the fraction that would be correctly predicted by assuming that the probability equals the mean proportion in the sample.

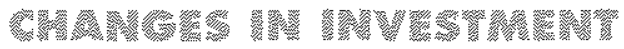

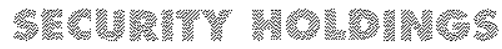

Regression models using three different measures of changes in investment security holdings are estimated to detemine if changes in the investment portolio are made in the quarer that SFAS 115 is adopted. The
2.

\section{Results of Probit Estimation of Early Adoption Decision}

\begin{tabular}{|c|c|c|}
\hline Voriable & & \\
\hline Intercept & $\begin{array}{ll}0.248 & 0.029 \\
(2389) & (0.448)\end{array}$ & $\begin{array}{c}0.020 \\
(0: 159)\end{array}$ \\
\hline Levergge rotio & $(-2768)$ a & $\begin{array}{r}-2.766 \\
-2.021)\end{array}$ \\
\hline Levergqe & $\begin{array}{r}-0162 \\
(-2700)\end{array}$ & \\
\hline Leverage & $\begin{array}{r}0.109 \\
-1.859)\end{array}$ & \\
\hline Leverage, & $\begin{array}{r}-0.015 \\
(-0.266)\end{array}$ & \\
\hline Refurn ons equity & $\begin{array}{ll}0524 & 0.475 \\
0.953) & 07731)\end{array}$ & $\begin{array}{l}0.438 \\
(1600)\end{array}$ \\
\hline Ulerealzed lolding goins & & $\begin{array}{l}4811 \\
(1,000)\end{array}$ \\
\hline Post excess gains & $\begin{array}{l}37,313) \quad 37.419 \\
(1,503) \quad(1.604)\end{array}$ & $\begin{array}{l}49.476 \\
\text { (1.889) }\end{array}$ \\
\hline Investnenis, & & $\begin{array}{l}0.385 \\
(0.825)\end{array}$ \\
\hline Invesiments, smatras, & & $\begin{array}{r}-0,704 \\
(-1894)\end{array}$ \\
\hline Irvestments, noturth & & $\begin{array}{c}0.338 \\
(1.274)\end{array}$ \\
\hline Interest vote contrats & & $\begin{array}{l}0,156 \\
(2490)\end{array}$ \\
\hline Pee? ? & $(-0.077-0.076$ & -0.051 \\
\hline Peer 1 & $\begin{array}{l}0.032 \quad 0.037 \\
(0.400) \quad(0.570)\end{array}$ & 0.143 \\
\hline Peert & $\frac{-0.097}{(-1.451)(-1.081}$ & $\begin{array}{c}0.022 \\
(0.238)\end{array}$ \\
\hline Peers & $\begin{array}{c}-0.037-0.037 \\
-0.465)(-0.500)\end{array}$ & $\begin{array}{c}0.096 \\
(0.953)\end{array}$ \\
\hline Peer 6 & $\begin{array}{ll}0.005 & 0.001 \\
0.068) & (0.012)\end{array}$ & $\begin{array}{l}0.180 \\
\text { [1118) }\end{array}$ \\
\hline probogity & & \\
\hline laie acopoters & 0.402 & 0.374 \\
\hline \&aty adoptess & $0.491^{1+x} \quad 0.494^{*}$ & $0.525^{*}$ \\
\hline merding corrody & $0.657^{*} 0.626^{*}$ & $0.669^{\circ}$ \\
\hline Psolo $-\mathrm{B}(\%)$ & $6055 \quad 7.203$ & 12020 \\
\hline
\end{tabular}

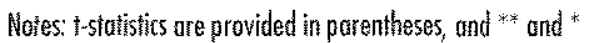
indicate stotisiental signifience of the 0.01 and 0.05 levels in oither the difference in means for eally ond lato adopters, or in the difference between the fraction carrectiy preditod and the proporiton of enty versus late adopiers in the sample.

\footnotetext{
For the model prosented in the thind column, hate roefficient on this veritule is only sigititiont of the 6 percent level wising o onethiles test.
} 
first measure examined is the change in the maturity-weighted invesiment portfolio. This variable measures both changes in the proportion of assets held in investment securities and changes in the maturity of the securities held. The second measure examined is the change in total investments. This variable measures only the change in the proportion of assets held as securities, ignoring changes in the maturity of the securities. The third measure is an adjusted maturity-weighted measure designed to eliminate changes in the weighted maturity of the portfolio that occur merely due to changes in the proportion of assets held in investment securities.

These three measures provide information on the overall change in investment security holdings and the two components of that change. Changes in the investment portfolio may occur for reasons other than the accounting change, such as changes in interest rates. Determining the expected change would require a comprehensive model of investment portfolio management. If the change in investment portfolio holdings associated with this accounting change occurs in the quarter that the standard is adopted, then the bank holding companies that did not adopt SFAS 115 during the quarter can be used as a control group. If the non-adopters provide a measure of the changes that would have occurred in the absence of the accounting standard, then the difference between the adopters and non-adopters can be used to determine the change due to the accounting standard. This is a common approach used to study treatment effects and program effectiveness.

A common problem in these studies is that participants often choose the group that they are in and therefore may be different for reasons other than the treatment or program. In this case, the period of adoption of SFAS 115 is not random and early adopters are different in a variety of ways from late adopters. Correction of the self-selection bias that results requires that these differences in characteristics be used to predict who will choose to be included in each group. The estimates from this prediction model can then be used to construct a variable that corrects for the bias that occurs because we cannot observe the values of the dependent variables for the alternative choice. This self-selection variable is computed using the predicted probabilities from the probit estimation of early adoption of SFAS 1.5 in the last colume in Table 4.2 The coefficient on this variable can be used to determine if the conclusion drawn from the estimation would have been affected by a self-selection bias.

The importance of reducing reported equity volatility is measured using the average leverage ratio and the average return on equity. The cost of increasing equity volatility is assumed to be negatively related to the level of these ratios and, therefore, the lower the average leverage ratio and average return on equity, the greater the expected reduction in the maturity of the investment portfolio.

Several control variables are also included in the regression to capture other factors that may be important in explaining the change in investment portfolio holdings. Since changes in maturity may depend on the initial maturity, the weighted average maturity of the investment portfolio at the end of the second quarter of 1993 is included in these regressions. In addition, the size of the bank holding company may be important in explaining the desired holdings. Peer group dummy variables are also included as control variables. Finally, the desired investment portfolio holdings may depend on the bank holding company's hedging activity and, therefore, an indicator variable for the existence of interest rate contracts is included.

\section{Estmotion Resulh}

Table 5 reports the results of the analysis of change in investment portfolio holdings for the fourth quarter of 1993 and Table 6 reports the results for the first quarter of 1994. Three regression models are estimated. The significantly negative coefficient on the early adoption dummy in the fourh quarter of 1993 , and the significantly positive coefficient on that variable in the first quarter of 1994 for the maturity-weighted and total-investments equations provide evidence that bank holding companies reduced both the proportion of assets held in the investment portfolio and the maturity of those investments in the quarter that they adopted SFAS 115. 
Given a weighted-average maturity of the investment portfolio on June 30,1993 , of 1.21 , the coefficient of -0.318 on the early adoption variable reported in column one indicates approximately a 27 percent decrease in the ratio of the maturity-weighted investment securities to assets resulting from the adoption of SFAS 115. Part of this decline is due to a decrease in the proportion of assets held in the investment portfolio. A coefficient of 0.045 on the early adoption variable in the regression examining the change in the ratio of investment securities to assets implies a 16 percent decline in the size of the investment portfolio, given an average ratio of investment securities to assets of 28 percent at the end of June 1993.

The significant coefficient on the selfselection variable indicates that the estimates would be biased if this variable were not included. In addition, the sign on the coefficient on this variable indicates the direction of the bias on the early adoption variable if the selectivity correction were omitted. The positive coefficients on the self-selection variable in the fourth quarter of 1993 regressions imply an upward bias on the coefficient on the early adoption variable without the selectivity correction, indicating that the estimated change in the investment portfolio holdings for the early adopters would have been understated. The opposite is true for the first quarter of 1994 regressions.

The significantly negative coefficient on the average leverage ratio in the fourth quarter of 1993 provides evidence of crosssectional differences in the concern over increased capital volatility resulting from the adoption of SFAS 115. I find little evidence that the average leverage ratio was important in explaining the change in investment portfolio holdings in the first quarter of 1994. In addition, I find litule evidence that the average return on equity is important in explaining the changes in either quarter ${ }^{13}$

Once other factors have been controlled for, the size of the bank holding company generally does not appear to be important in explaining the change in the maturity of the investment portfolio, although these variables are important in explaining the change in the proportion of assets held in the investment

\section{ans}

Estimation Results for Changes in Investment Security Moldings in the Fourth Quarter of 1993

\begin{tabular}{|c|c|c|c|}
\hline Variable & $\Delta$ lnvestment $_{\mathrm{wA}}$ & $\Delta$ Investment & $\Delta$ Investment $_{\text {Awa }}$ \\
\hline Interept & $(0.283$ & $\begin{array}{l}0.035 \\
(2.722)\end{array}$ & 0.243 \\
\hline Eorly cidoption & $\begin{array}{r}-0.318 \\
-2.540)\end{array}$ & $\begin{array}{r}-0.045 \\
(-2.922)\end{array}$ & $\begin{array}{r}-0.265 \\
(-2.404)\end{array}$ \\
\hline Seltseledion & $\begin{array}{l}0.209 \\
(2.662)\end{array}$ & $\begin{array}{l}0.025 \\
(2.608)\end{array}$ & $\begin{array}{r}0.178 \\
(2.589)\end{array}$ \\
\hline Mveroge leverogerolo & $\begin{array}{r}-2.366 \\
(-2.569)\end{array}$ & $(-2.441)$ & $\begin{array}{r}-1.924 \\
(-2.374)\end{array}$ \\
\hline Averuge refurn on equity & $\begin{array}{l}0.815 \\
(1.815)\end{array}$ & $\begin{array}{l}0.016 \\
(0.258)\end{array}$ & $\begin{array}{l}0.653 \\
(1652)\end{array}$ \\
\hline Irvesinen! & $\begin{array}{r}0.034 \\
2.034)\end{array}$ & & $\begin{array}{r}-0.038 \\
(-2.138)\end{array}$ \\
\hline Hestrent: & & $(-0.034)$ & \\
\hline Interest tote conicot & $\begin{array}{l}0.029 \\
(0.630)\end{array}$ & $\begin{array}{l}0.014 \\
(2.217)\end{array}$ & $\begin{array}{l}0.017 \\
(0.417)\end{array}$ \\
\hline Peer 2 & $\begin{array}{r}0.024 \\
(0.483)\end{array}$ & $(-0.001$ & $\begin{array}{l}0.031 \\
00.727)\end{array}$ \\
\hline $\mathrm{Peer} 3$ & 0.071 & $\begin{array}{l}0.019 \\
(2.568)\end{array}$ & $\begin{array}{l}0.057 \\
(1.172)\end{array}$ \\
\hline Peet 4 & $\begin{array}{l}0.024 \\
0.437)\end{array}$ & $\begin{array}{l}0.017 \\
(2.266)\end{array}$ & $\begin{array}{l}0.014 \\
(0.279)\end{array}$ \\
\hline Peer 5 & $\begin{array}{l}0.159 \\
(2.549)\end{array}$ & $\begin{array}{c}0.038 \\
(4.495)\end{array}$ & $\begin{array}{r}0.112 \\
\{2,035\}\end{array}$ \\
\hline Peero & $\begin{array}{l}0.083 \\
(1.298)\end{array}$ & $\begin{array}{r}0.025 \\
(2.89)\end{array}$ & $\begin{array}{c}0.059 \\
(1.036)\end{array}$ \\
\hline Ad) $R^{2}(\%)$ & 8.37 & 11.03 & 7.43 \\
\hline
\end{tabular}

Hote: f-statistics are provided in parentheses.

portfolio. In the fourth quarter of 1993 , the weighted average maturity of the investment portfolio is important in explaining the change in the maturity, while the existence of interest rate contracts is important in explaining the change in the first quarter of 1994.

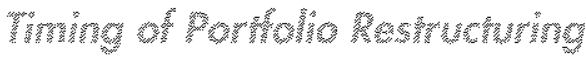

To test the reasonableness of the assumption that changes in investment portfolio holdings are made in the quarter that SFAS 115 is adopted rather than before or after, I compare the proceeds from securities sales during 1993 for bank holding companies that adopted in 1993 versus those that adopted in 1994.1 also compare annual rather than

\footnotetext{
"The regressions were diso estintied nllowing the coefficients on the arerage levetoge ratio and the avergege retura on equity to be dif ferent for enchy and late riclopiers. These coefficients were statistically significont anly for the levesoge refie in the fourtit civerter of 1993 , and the conclusions drowat gbout chatiger in the investment porfolio in the quarter of actopition of SEAS 115 were unchunged usiag initis specificeten
} 


\section{(1).}

\section{Estimation Results for Changes in Investment Security Holdings in the First Quarter of 1994}

\begin{tabular}{|c|c|c|c|}
\hline Variable & $\Delta$ lnvestment $_{\text {mA }}$ & $\Delta$ lnvestment & $\Delta$ Investment ${ }_{\text {AWA }}$ \\
\hline Intepcep/ & $\begin{array}{c}-0.052 \\
(-0.468)\end{array}$ & $\begin{array}{c}-0.022 \\
(-1.598)\end{array}$ & $\begin{array}{c}-0.002 \\
(-0.016)\end{array}$ \\
\hline Eorly atoption & $\begin{array}{c}0.263 \\
(1.851)\end{array}$ & $\begin{array}{c}0.032 \\
(2.050)\end{array}$ & $\begin{array}{c}0.181 \\
(1.402)\end{array}$ \\
\hline Seltselection & $\begin{array}{c}-0.153 \\
\{-1.725\}\end{array}$ & $\begin{array}{r}-0.019 \\
(-1.947)\end{array}$ & $\begin{array}{c}-0.103 \\
(-1.282)\end{array}$ \\
\hline Average leveroge rolía & $\begin{array}{r}0.311 \\
(-0.288)\end{array}$ & $\begin{array}{l}0.138 \\
(1.054)\end{array}$ & $\begin{array}{c}-0.490 \\
(-0.500)\end{array}$ \\
\hline Averoge retum on equity & $\begin{array}{r}-0.311 \\
(-0.481)\end{array}$ & $\begin{array}{r}-0.022 \\
-0.282)\end{array}$ & $\begin{array}{r}-0.222 \\
(-0.379)\end{array}$ \\
\hline nuestinent, & $\begin{array}{c}0.000 \\
(0.016)\end{array}$ & & $\begin{array}{r}-0.002 \\
(-0.105)\end{array}$ \\
\hline byestment & & $(-0.024$ & \\
\hline Iflerest rale contrad & $\left(\begin{array}{l}0.084 \\
(1576)\end{array}\right.$ & $\begin{array}{r}0.000 \\
(-0.069)\end{array}$ & $\begin{array}{r}0.076 \\
(-1.567)\end{array}$ \\
\hline Beer 2 & $\begin{array}{l}0.093 \\
11682)\end{array}$ & $\begin{array}{l}0.009 \\
{[1341]}\end{array}$ & $\begin{array}{l}0.079 \\
(1.567)\end{array}$ \\
\hline Peer 3 & $\begin{array}{l}0.071 \\
(1.120)\end{array}$ & $\begin{array}{l}0.009 \\
(1.186)\end{array}$ & $\begin{array}{l}0.064 \\
(1.115)\end{array}$ \\
\hline Per 4 & $\begin{array}{r}0.092 \\
(1.462)\end{array}$ & 0.012 & $\begin{array}{l}0.070 \\
(1.223)\end{array}$ \\
\hline Peer 5 & $\begin{array}{l}0.002 \\
(0.029)\end{array}$ & $\begin{array}{r}0.005 \\
(0.575)\end{array}$ & $\begin{array}{c}0.002 \\
(0.028)\end{array}$ \\
\hline Peer 6 & $\begin{array}{l}0.051 \\
(0.667)\end{array}$ & $\begin{array}{c}0.099 \\
10.987)\end{array}$ & $\begin{array}{r}0.048 \\
(0.694)\end{array}$ \\
\hline $\mathrm{Ad}(\mathrm{X})$ & 2.28 & -0.40 & 123 \\
\hline
\end{tabular}

Note: t-stalistics are provided in parentheses.

\footnotetext{
${ }^{14}$ The lergest tostatistic found in these estimations wes 3.315 and ganer ally the t-stotistics wee less that 1 .
}

quarterly proceeds because only annual proceeds are disclosed in the financial statements. If early adopters change investment portfolio holdings during 1993, then, cor recting for the self-selection bias, these bank holding companies should have higher proceeds during this period. For proceeds on sales of investment securities, I conduct a regression analysis similar to the analysis for changes in investment portfolio holdings. The results of the regression analysis of turnover of the investment portfolio in 1993 indicate that controlling for past portfolio tumover, bank holding company peer group, and the self-selection bias, early adopters had a higher portfolio turnover in 1993 than late adopters. The results of this regression provide some support for the assumption that changes in the investment portfolio were made in the period when SFAS 115 was adopted.

In addition, the regressions performed during the period of the accounting change are also estimated for the same quarters during 1991 and 1992 . Finding no significant difference in the change in invesment portfolio holdings during these early periods for companies that adopted SFAS 115 early versus those that did not would provide reassurance that any differences found during the SFAS 115 adoption period are actually attributable to the accounting change. In the estimation of the equations reported in Tables 4 and 5 for the same quarters in 1991 and 1992, I find no evidence of differences between the carly adopters and other companies. ${ }^{14}$

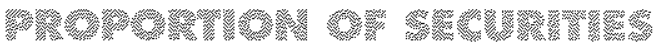

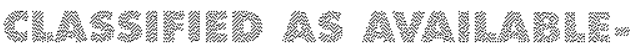

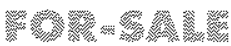

An alternative approach that can be used to reduce the volatility in reported equity that results from the adoption of SFAS 115 is to reduce the proportion of securities classified as available-for-sale. A regression model is estimated to examine how the desire to maintain flexibility in investment portfolio management and to reduce volatility of reported capital affects the proportion of investment securities classified as available-for-sale.

The importance of liquidity and interest rate risk management is measured using past portfolio turnover. The beneft of being able to sell investment securities for liquidity or interest rate risk management is assumed to be higher for bank holding companies, the more active their management of the investment portfollo has been. Portfolio turnover is used to measure the level of portfolio management activity. Bank holding companies with higher portfolio turnover are expected to classify a larger proportion of their investments in the available-for-sale portfolio.

The importance of influencing reported earnings through the sale of securities is measured using the past excess securities gains recognized. The benefit of being able to recognize gains on the sale of securities 
to influence earnings is assumed to be higher for bank holding companies that recognize a disproportionate amount of gains on security sales. Excess securities gains recognized are computed as the difference between the ratio of recognized gains to the market value of investment securities, and the ratio of unrealized gains to the market value of investment securities multiplied by the portfolio turnover. This measure assumes that in the absence of earnings, management gains will be recognized in proportion to the unrealized gains. The average past securities gains recognized are used as an alternative measure of the desire to influence reported earnings through the recognition of gains on securities sales.

As for the change in investment portfolio maturity regression, the importance of reducing reported equity volatility is measured using the leverage ratio and return on equity. The cost of increasing equity volatility is assumed to be negatively related to the level of these ratios and, therefore, the proportion of securities classified as available-for-sale is assumed to be positively related to the level of these ratios.

I also include several control variables in the regression to capture other factors that may be important in explaining the proportion of securities classified as available-for-sale. Since the sensitivity of the investment portfolio value to changes in interest rates will depend on the timing of cash flows from the securities held, I include a measure of the maturity of the investment portfolio. In addition, the size of the bank holding company may be important in determining how active the investment portfolio management is, and may also be related to the other measures included in the regression. Therefore, I add peer group dummy variables as control variables.

\section{Estwethen hesuls}

Table 7 reports the results of regression analysis of the proportion of securities classified as available-for-sale. The results show that reducing volatility in reported capital as well as maintaining flexibility in managing liquidity and interest rate risk, and in influencing reported earnings are important in deciding what proportion of securities to classify as available-for-sale.

\section{(3)}

Estimation Results for Proportion of Securities Classified as Available-for-Sale

\begin{tabular}{|c|c|c|c|}
\hline Voriable & & & \\
\hline thercept & $\begin{array}{r}0.254 \\
(2.399)\end{array}$ & $\begin{array}{c}0.258 \\
(2.434)\end{array}$ & $\begin{array}{c}0.218 \\
(2.053)\end{array}$ \\
\hline Average leveroge rotio & $\begin{array}{c}1.830 \\
(1.480)\end{array}$ & $\begin{array}{l}1.883 \\
(1.520)\end{array}$ & $\begin{array}{l}1.825 \\
(1.492)\end{array}$ \\
\hline Avergage return on equity & $\begin{array}{l}2.035 \\
(2.139)\end{array}$ & $\begin{array}{c}2.007 \\
(2.108)\end{array}$ & $\begin{array}{c}2.333 \\
(2.458)\end{array}$ \\
\hline Positive past exeess gains & & & $\begin{array}{l}39.735 \\
(2.431)\end{array}$ \\
\hline Past excess gäins & $\begin{array}{l}13.142 \\
(2.244)\end{array}$ & $\begin{array}{l}12.451 \\
(2.104)\end{array}$ & $\begin{array}{r}1.524 \\
(0.203)\end{array}$ \\
\hline Past gains & & $\begin{array}{l}66.574 \\
(0.850)\end{array}$ & \\
\hline Post portiolio turnover & $\begin{array}{c}0.462 \\
(3.407)\end{array}$ & $\begin{array}{l}0.398 \\
(2.560)\end{array}$ & $\begin{array}{c}0.338 \\
(2.354)\end{array}$ \\
\hline linvestment & $\begin{array}{l}0.666 \\
(1.506)\end{array}$ & $\begin{array}{l}0.675 \\
(1.524)\end{array}$ & $\begin{array}{c}0.741 \\
(1.689)\end{array}$ \\
\hline Investment $_{\text {rnoturises }}$ & $\begin{array}{l}-0.115 \\
(-0.393)\end{array}$ & $\begin{array}{l}-0.213 \\
(-0.677)\end{array}$ & $\begin{array}{c}-0.080 \\
(-0.277)\end{array}$ \\
\hline 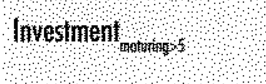 & $\begin{array}{c}0.317 \\
(1.397)\end{array}$ & $\begin{array}{c}0.249 \\
(1.033)\end{array}$ & $\begin{array}{r}0.360 \\
(1.596)\end{array}$ \\
\hline Peer ? & $\begin{array}{c}-0.072 \\
(-1.016)\end{array}$ & $\begin{array}{c}-0.062 \\
(-0.863)\end{array}$ & $\begin{array}{c}-0.074 \\
(-1.053)\end{array}$ \\
\hline Peer 3 & $\begin{array}{c}-0.039 \\
(-0.564)\end{array}$ & $\begin{array}{l}-0.030 \\
(-0.423)\end{array}$ & $\begin{array}{l}-0.036 \\
(-0.522)\end{array}$ \\
\hline Peer 4 & $\begin{array}{c}0.003 \\
(0.046)\end{array}$ & $\begin{array}{c}0.007 \\
(0.098)\end{array}$ & $\begin{array}{c}0.005 \\
(0.072)\end{array}$ \\
\hline Peer 5 & $\begin{array}{c}-0.036 \\
(-0.442)\end{array}$ & $\begin{array}{c}-0.029 \\
(-0.351)\end{array}$ & $\begin{array}{c}-0.036 \\
(-0.445)\end{array}$ \\
\hline Peer 6 & $\begin{array}{c}-0.057 \\
(-0.647)\end{array}$ & $\frac{-0.054}{(-0.615)}$ & $\begin{array}{r}-0.048 \\
(-0.553)\end{array}$ \\
\hline Add $R^{2}(\%)$ & 2.78 & 2.66 & 4.84 \\
\hline
\end{tabular}

Note: t-stolistics are provided in parentheses.

The significantly positive coefficient on portfolio turnover suggests that bank holding companies that have more actively engaged in liquidity and interest rate risk management in the past classify a higher fraction of their investment securities in the available-for-sale portfolio. ${ }^{15}$ Similarly, the significantly positive coefficient on excess gains on securities sales indicates that bank holding companies that have used gains on the sale of securities to influence reported earnings and capital in the past classify a higher proportion of securities as available-for-sale. The positive coefficients on both the leverage ratio and return on equity 
suggest that bank holding companies with more capital and higher earnings are more willing to incur the increased volatility in reported equity that will occur when a higher fraction of their investments are included in the available-for-sale portfolio. The coeffcients on the average leverage ratio, however, are only significant at the 7 percent level using a one-tailed test.

The size of the bank holding company and the tuaturity of the investment portfolio are generally not important in explaining the proportion of securities classified as avatable-for-sale.

\section{준}

Bank managers and regulators have opposed the adoption of SFAS 115 , claiming that the increased volatilty in reported equity caused by this accounting standard is not indicative of true volatility in equity and will cause bank holding companies to altet their investment portfol to management. In addition, they have argued that banks will continue to have opportunities for manipulating the numbers reported in the financial statements.

Based on bank holding companies response to the implementation of SFAS 115 , this article provides several pieces of evidence that suggest that bankers' and regulators' concerns about the impact of SFAS 115 are well-founded. The decrease in both the proportion and maturity of investment securities held in the quarter when SFAS 115 was adopted, and the reduction in the proportion of securities classified as available-for-sale as bank holding companies' average leverage ratio and average return on equity decline indicate that concerns about volatility in reported equity induced by SFAS 115 led to a change in investment port folio management.

The importance of the leverage ratio and return on equity in the decision to adopt SFAS 115 early, and the higher proportion of securities classified as available-for-sale if excess securities gains have been recognized in the past indicate that management can still influence the numbers reported in the fnancial statements under SFAS 115. Management of the investment portfolio under SFAS 115 appears to be affected both by a desire to reduce the volatility in reported capital and the desire to maintain flexibility to influence reported earnings through the recognition of gans on secturty sales.

If the documented changes in investment portfolio management continue, they could have important consequences for the banking industry and the economy. Although no attempt is made in this article to assess how costly these changes will be, shortening the maturity of the investment portfolio may result in a reduction in the interest income eamed by bank holding companies or may increase their interest rate risk. Reduction of the llexibility to sell securities from the held-to-maturity portlolio may increase the cost of managing liquidity and interest rate risk. Reduced flexibility in liquidity management could make banks unable to meet increases in loan demand, thereby decreasing the availability of credit. Increased exposure to changes in interest rates could make the banking industry more volatile.

Even in the absence of changes in the investment portfolio, including the effects of SFAS 115 in regulatory capital could be costly if bank holding companies must maintain additional capital or if regulatory actions are taken against viable bank holding companies as a result of the change in accounting method. The recent decision by regulators to exclude the effects of SFAS 115 from the definition of regulatory captal ratios may lead to further changes in investment portolio management that will ameliorate these effects.

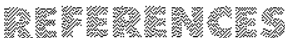

Borth, May E., Woyne R. Londsman, and sames M. Wathen. "Foir Volue Accounting: Effects on Baiks' Eanings Volotitity, Regulatory Capital, and Volue of Contractual Cash Flows," Jound of Bonking and finonce (fothoming 1995).

Berget, Allen N., Katheen K. King, and Jomes M. OBrien. "The Limitotions of Market Volue Accounting And a More Realistic Alternative," Jound of Bonking and Finonce (September 1991). pe. 75383 .

Corey, Mork. "Partiol Morke: Value Accounting, Bank Capital Valatility, and Bank Risk, "Joumd of Banking and Finance (forthroming).

"Snacking ond Smoothing: Gains Trading of Investment Account Securties by Comenercal Barks," Working Poper, Boord of Govenors of the Federd Reserve System (June 29, 1994). onetoiled test. 


\section{Minifin \\ EANUARY/FEBRUARY 195}

Enst \& Young. A Notional Survey of thief financial and Chief Investment Officers in 216 Financid Sevices Institutions, 1993.

Enst \& Yound. A Follow-llo Sunvey on the impact of the Implementction of FAS 115,1994

Greene, Willam H. Econometric Andysis, 2nd edition. Marmillon, 1993.

Moddala, 6.5. Lmited-Denendent and Qualtative Variables in Economefrics (Econometic Society Monogramh No. 3 ). Combridge Uniwersity Pess, 1983.
Mengle, Guvid L, and John R. Walter. "How Market Wolue Accounting Woudd Affeci Banks, Proceediags of o Conferente on Bonk Stucture and Competition," Faderal Reserve Bonk of Chicago, May 1-3, 1991.

Shaffer, Sherrill. "Makking Banks to Morket," Federal Reserve Bonk of Phitadelphic Bushess Review (Juy/August 1992), ap. 1322. 